\begin{tabular}{|c|c|}
\hline JMM & JURNAL MAGISTER MANAJEMEN \\
UNIVERSITAS MATARAM \\
UNRAM
\end{tabular}

\title{
PENGARUH BUDAYA ORGANISASI DAN GAYA KEPEMIMPINAN TERHADAP MOTIVASI KERJA PEGAWAIPADA SEKRETARIAT DAERAHKABUPATEN LOMBOK TENGAH
}

\author{
Mastur ${ }^{1}$ \\ Zainal Abidin² \\ Alamsyah $^{3}$
}

\begin{abstract}
This study was conducted to determine the effect of organizational culture and effectiveness of leadership style to motivate employees to work at the Regional Secretariat of Central Lombok Regency. The problem of motivation is a topic that never ceases to be extracted in order to achieve an understanding of the theoretical with the practical ability in everyday life, especially motivating employees in government agencies.

This research is an associative causal, with 137 respondents. Samples determined using sampling random sampling technique. Data collection toolwas questionnaire with Likert scale. Data were analyzed by using multiple linear regressions.

The results showed that the effectiveness of the organizational culture and leadership style has a significant and positive effect on the motivation of employees either partially or simultaneously.Leadership style wasfound as a dominant influencing factor in this research. This study found that organizational culture conducive and positive increase employee motivation to work on, as well as effective leadership will further enhance the work motivation. Harmony and atmosphere that makes employees feel comfortable in working and caring leaders to listen to their employees should be improved so that the employee work motivation will automatically increase.
\end{abstract}

\section{Keywords: Organizational Culture, Leadership Style and Effectiveness of Work Motivation.}

\section{PENDAHULUAN}

\subsection{Latar Belakang}

Proses pembangunan di era otonomi daerah yang berlangsung saat ini tidak dapat dilepaskan dari peran penting pegawai dalam pembangunan organisasi. Sumber daya manusia adalah salah satu faktor produksi yang paling dominan dan sangat berperan aktif dalam pencapaian visi dan misi organisasi. Dalam pencapaian tujuan tersebut, organisasi memerlukan suatu pendorong atau motivasi kepada sumber daya manusianya.Hasibuan (2010), motivasi adalah suatu keinginan atau kebutuhan yang mendorong dan atau mempengaruhi seseorang untuk melakukan gerak yang menciptakan adanya kegairahan kerja, bekerjasama, bekerja efektif dan berintegrasi untuk mencapai tujuan. Menurut McClelland dalam Tampubolon, (2008:92), apabila

\footnotetext{
${ }^{1}$ Mahasiswa Program Magister Manajemen Pascasarjana Universitas Mataram

${ }^{2}$ Dosen Program Magister Manajemen Pascasarjana Universitas Mataram

${ }^{3}$ Dosen Program Magister Manajemen Pascasarjana Universitas Mataram
} 
seseorang yang sangat mendesak untuk memenuhi kebutuhan itu, maka akan memotivasi orang tersebut untuk berusaha keras memenuhi kebutuhannya.

Goelman et.al (2004:198), menyatakan bahwa pemimpin mempunyai daya maksimal untuk memanipulasi emosi setiap orang. Jika emosi orang-orang didorong kearah antusiasme, motivasi akan meningkat, sebaliknya jika motivasi seseorang didorong kearah kebencian dan kecemasan, maka motivasi akan memancing keluar dari sisi terbaik setiap orang. Menurut Gibson (1996:5) menyatakan bahwa kepemimpinan merupakan suatu usaha menggunakan gaya mempengaruhi dan tidak memaksa untuk memotivasi individu dalam mencapai tujuan. Dalam menjalankan kepemimpinannya, seorang pemimpin memiliki gaya yang merupakan norma perilaku seorang pemimpin dalam mempengaruhi pegawainya. Menurut Thoha (2010:49), "gaya kepemimpinan merupakan norma perilaku yang digunakan seseorang pada saat orang tersebut mencoba mempengaruhi perilaku orang lain, seperti yang ia lihat". Pada birokrasi pemerintah gaya kepemimpinan yang perlu diterapkan adalah gaya kepemimpinan situasional sebagaimana pendapat Pasolong (2010:137) “pemimpin birokrasi perlu menerapkan kepemimpinan situasional oleh Hersey dan Blanchard, dengan menerapkan gaya kepemimpinan yang sesuai dengan tingkatkematangan pegawai yang menjadi bawahannya agar motivasi dapat ditingkatkan".

Gaya kepemimpinan dalam memberikan arahan kepada bawahan, ada dua perilaku yang dilakukan, yaitu : perilaku mengarahkan dan perilaku yang mendukung. Menurut Thoha (2010:64), perilaku mengarahkan dapat dirumuskan sebagai sejauh mana seorang pemimpin melibatkan diri dalam komunikasi satu arah. Bentuk pengarahan dalam komunikasi satu arah ini antara lain, menetapkan peranan yang seharusnya dilakukan pengikut, memberitahukan pengikut tentang apa yang seharusnya dikerjakan, dimana melakukan hal tersebut, bagaimana melakukannyadan melakukan pengawasan secara ketat kepada pengikutnya.

Selain kepemimpinan, budaya organisasi merupakan faktor yang mempengaruhi motivasi kerja. Harriss dan Mossholder (1996:128), menyebutkan bahwa budaya organisasi berdiri sebagai pusat seluruh faktor yang berasal dari manajemen sumber daya manusia.Budaya organisasi dipercaya mempengaruhi sikap individu mengenai hasil, seperti komitmen,moral, kepuasan dan motivasi kerja.

Faktor budaya organisasi juga turut mempengaruhi motivasi dari pegawai. Menurut Gibson, Ivanichevic dan Donelly, 1988 dalam Soetopo (2010:122), budaya organisasi adalah kepribadian organisasi yang mempengaruhi cara bertindak individu dalam organisasi. Dari defenisi diatas, budaya organisasi dapat mempengaruhi cara bertindak pegawai karena budaya organisasi merupakan kepribadian dalam organisasi. Penelitiian ini didasari pada kenyataan bahwa dilingkungan Sekretariat Daerah Kabupaten Lombok Tengahmenurut survey awal atau pengamatan, terdapat berbagai hal yang perlu dikaji sebagaimana uraian diatas, diantaranya adalah masih banyak terjadi pegawai yang sering meninggalkan tugas pada jam kerja dan terlihat sering meja kosong pada saat kerja karena ditinggalkan oleh pegawai yang merokok sambil minum kopi di halaman belakang atau menonton $t v$ di ruang umum. 
Hal lain yang juga peneliti amati adalah masih banyak pegawai yang memberikan pekerjaan yang seharusnya mereka kerjakan pada pegawai honorer. Beberapa pegawai yang diamati terlihat memberikan pekerjaan tambahan kepada pegawai honorer untuk membantu mereka, sehingga beban kerja pegawai yang bersangkutan menjadi berkurang dan mereka dapat lebih santai di kantor.

Hal ini menunjukan ada masalah pada tanggung jawab pegawai, karena seharusnya seorang yang mempunyai tanggung jawab yang baik, tidak akan mempercayakan pekerjaan yang menjadi tanggung jawabnya pada orang lain, terlebih pegawai honorer belum tentu mempunyai pengalaman sebagaimana dirinya.

Permasalahan yang lain, pemimpin kurang memberikan kesempatan pada bawahannya, dengan berusaha mendengarkan perasaan pengikut tentangapa yang menjadi keluhan bawahan dan kendala yang ditemukan oleh bawahannya, serta ideide dari bawahan terkait dengan pekerjaannya. Komunikasi yang terjadi cenderung satu arah padahal tidak semua pegawai memiliki kemampuan yang sama, ada yang membutuhkan sedikit arahan namun ada juga yang membutuhkan banyak arahan dari pimpinan.

Ada hal-hal yang perlu diperhatikan oleh seorang pemimpin untuk dapat memotivasi pegawai diantaranya adalah : (a) hal-hal yang mendorong pegawai adalah pekerjaan yang menantang yang mencakup perasaan untuk berprestasi, bertanggungjawab, untuk bisa mencapai kemajuan sehingga dapat menikmati pekerjaan itu sendiri dan adanya pengakuan atas semuanya itu dari pimpinan. (b) halhal yang mengecewakan pegawai adalah terutama faktor yang bersifat semu atau berpura-purasaja pada pekerjaan, peraturan pekerjaan, penerangan, istirahat, sebutan jabatan, hak, gaji, tunjangan dan lain-lainnya. (c) pegawai kecewa, jika peluang untuk berprestasi terbatas. Mereka akan menjadi sensitif pada lingkungannya serta mulai mencari-cari kesalahan.

Pimpinan yang baik dalam mencapai tujuannya, memiliki visi dan misi sebagai rencana untuk menentukan strategi guna memajukan organisasinya.Pemimpin seperti itu merupakan pemimpin yang inovatif.Selain masalah kepemimpinan, pada sekretariat daerah kabupaten Lombok Tengah menunjukkan budaya organisasi yang tidak cukup menyenangkan.Hal ini diindikasikan dengan jarak manajemen terutama pimpinan dengan bawahan. Masih ada beberapa pimpinan yang mempunyai pandangan bahwa mereka harus dilayani dan menjadi tuan dalam organisasi tersebut. Sehingga bawahan berusaha melayani pimpinannya sebagai layaknya bos, bukan sebagai pimpinan birokrasi. Indikasi lain terlihat dengan kurang teraturnya pegawai dalam bekerja, masih banyak pegawai yang terlihat tidak rapi baik dari kerapian diri, maupun kerapian tempat kerja.

\subsection{Rumusan Masalah}

1) Apakah Gaya Kepemimpinan dan Budaya Organisasiberpengaruh signifikan secara simultan terhadap motivasi kerja pegawai pada Sekretariat Daerah Kabupaten Lombok Tengah 
2) Apakah Gaya Kepemimpinan dan Budaya Organisasiberpengaruh signifikan secara parsial terhadap motivasi kerja pegawai pada Sekretariat Daerah Kabupaten Lombok Tengah

3) Manakah diantara Gaya Kepemimpinan dan Budaya Organisasi yang memiliki pengaruh dominan terhadap motivasi kerja pegawai pada Sekretariat Daerah Kabupaten Lombok Tengah

\subsection{Tujuan Penelitian}

1) Untuk mengetahui Gaya Kepemimpinan dan Budaya Organisasiyang berpengaruh signifikan secara simultan terhadap motivasi kerja pegawai pada Sekretariat Daerah Kabupaten Lombok Tengah.

2) Untuk mengetahui Gaya Kepemimpinan dan Budaya Organisasiyang berpengaruh signifikan secara parsial terhadap motivasi kerja pegawai pada Sekretariat Daerah Kabupaten Lombok Tengah

3) Untuk mengetahui manakah diantara Gaya Kepemimpinan dan Budaya Organisasi yang memiliki pengaruh dominan terhadap motivasi kerja pegawai pada Sekretariat Daerah Kabupaten Lombok Tengah.

\section{KAJIAN PUSTAKA}

\subsection{Penelitian Terdahulu}

Agung Wibowo, (2008) meneliti tentang pengaruh Budaya Organisasi dan Kepuasaan Kerja Terhadap Motivasi Kerja dan Kinerja Karyawan (Studi pada unit Kantor Cabang BRI Pattimura Semarang). Hasil penelitian ini menunjukkan bahwa Budaya Organisasi secara langsung dapat mempengaruhi Motivasi Kerja karyawan Kantor Cabang BRI Pattimura Semarang.

Putu Arga Sujarwadi (2012) meneliti tentang Pengaruh gaya kepemimpinan terhadap kinerja pegawai Rumah Sakit Umum Provinsi Nusa Tenggara Barat. Hasil penelitian menunjukkan Kepemimpinan berpengaruh positif terhadap motivasi kerja pegawai Rumah Sakit Umum Provinsi Nusa Tenggara Barat

Setyowati Nugraheny (2009) meneliti tentang pengaruh kepuasan kerja, dukungan organisasi dan gaya kepemimpinan terhadap motivasi dalam meningkatkan kinerja karyawan (studi pada PT. Bank Mandiri Persero Tbk Kota Semarang). Hasil penelitian menunjukkan Gaya kepemimpinan mempengaruhi motivasi kerja dengan signifikan dan positif.

Subhan (2012) meneliti tentang Development of Work Stres Scale for Correctional Officers.Hasil penelitian menunjukkan bahwa Kepemimpinan mempengaruhi secara signifikan dan positif. 
Nuroctaviana, (2011) meneliti tentang hubungan antara budaya organisasi, motivasi, kepuasan kerja dan kinerja.Hasil penelitian Ada hubungan yang langsung dan signifikan antara budaya organisasi dan motivasi kerja.

\subsection{Landasan Teori}

\subsubsection{Motivasi Kerja}

Robbins (2003:107) mendefinisikan "motivasi sebagai kesediaan untukmengeluarkan tingkat upaya yang tinggi untuk tujuan-tujuan organisasi, yangdikondisikan oleh kemampuan upaya itu untuk memenuhi sesuatu kebutuhanindividual.Motivasi muncul akibat dari interaksi individu dengan situasi di lingkungannya". Sofyandi dan Garniwa (2007:38) menjelaskan bahwa "tingkat motivasi ini berlainan antara individu yang satu dengan individu yang lain dan antara individuindividu pada berbagai waktu yang berlainan".

\subsubsection{Indikator Motivasi Kerja}

Menurut Hamzah B. Uno (2009: 73) dimensi dan indikator motivasi kerja dapat dikelompokan sebagai berikut:

1. Motivasi internal

a) Tanggung jawab dalam melaksanakan tugas

b) Melaksanakan tugas dengan target yang jelas

c) Memiliki tujuan yang jelas dan menantang

d) Ada umpan balik atas hasil pekerjaannya.

e) Memiliki rasa senang dalam bekerja.

f) Selalu berusaha mengungguli orang lain.

g) Diutamakan prestasi dari apa yang dikerjakannya.

2. Motivasi eksternal

a) Selalu berusaha memenuhi kebutuhan hidup dan kebutuhan kerjanya.

b) Senang memperoleh pujian

\subsubsection{Gaya Kepemimpinan}

Kepemimpinan merupakan kemampuan untuk mempengaruhi suatu kelompok kearah tercapainya suatu tujuan. Kepemimpinan adalah pribadi yang dijalankan dalam situasi tertentu, serta diarahkan melalui proses komunikasi kearah pencapaian satu atau beberapa tujuan tertentu. Kepemimpinan menyangkut proses pengaruh sosial yang disengaja dijalankan oleh seseorang terhadap orang lain untuk menstruktur aktivitas dan pengaruh didalam kelompok atau organisasi (Robbins, 2003:124).

Kepemimpinan yang akan dilihat disini adalah gaya kepemimpinan dalam organisasi yang diterapkan oleh pimpinan terhadap bawahannya. Gaya kepemimpinan adalah suatu cara bagaimana seorang pemimpin menjalankan tugasnya. Hani Handoko 
(1995:98), mengemukakan gaya kepemimpinan adalah bagaimana seorang pemimpin dapat dengan tepat mengarahkan tujuan perseorangan dan tujuan organisasi.

\subsubsection{Indikator Gaya Kepemimpinan}

Winardi (2000:109) mengungkapkan bahwa kepemimpinan yang efektif memiliki ciri-ciri yaitu:

a) Mampu menginspirasi kepercayaan pada orang-orang

b) Persistensi (tekad bulat) untuk mencapai tujuan yang telahditetapkan

c) Kemampuan untuk berkomunikasi tanpa menimbulkan kesalah pahaman

d) Kesediaan mendengarkan orang lain secara respektif

e) Perhatian jujur terhadap manusia

f) Memahami manusia dan reaksi-reaksi yang ditimbulkannya

g) Objektivitas dan

h) Kejujuran

\subsubsection{Budaya Organisasi}

Kreitner dan Kinicki (1995:532); mengemukakan bahwa budaya orgainsasi adalah perekat social yang mengingat anggota dari organisasi. Nampaknya agar suatu karakteristik atau kepribadian yang berbeda-beda antara orang yang satu dengan orang yang lain dapat disatukan dalam suatu kekuatan organisasi maka perlu adanya prekat sosial (dalam Koesmono,2005:78).

Budaya organisasi didefinisikan sebagai suatu kerangka kerja kognitif yang memuat sikap-sikap, nilai-nilai, norma-norma dan pengharapan-pengharapan bersama yang dimiliki oleh anggota-anggota organisasi (Greenberg dan Baron, 2000).Budaya organisasi berkaitan dengan konteks perkembangan organisasi, artinya budaya berakar pada sejarah organisasi, diyakini bersama-sama dan tidak mudah dimanipulasi secara langsung (Schenieder, 1996, dalam Cahyono 2005:101).

Menurut Stoner (1996) dalam Waridin \& Masrukhin (2006:98) budaya (culture) merupakan gabungan kompleks dari asumsi, tingkah laku , cerita, mitos, metafora dan berbagai ide lain yang menjadi satu untuk menentukan apa arti menjadi anggota masyarakat tertentu. Budaya organisasi atau corporate culture sering diartikan sebagai nilai-nilai, simbol-simbol yang dimengerti dan dipatuhi bersama, yang dimiliki suatu organisasi sehingga anggota organisasi merasa satu keluarga dan menciptakan suatu kondisi anggota organisasi tersebut merasa berbeda dengan organisasi lain.

\subsubsection{Indikator Budaya Organisasi}

Hofstede, et.al (1993:108), mengemukakan indikator budaya organisasi yaitu: (1). Profesionalisme pegawai, (2). Jarak dari manajemen. (3). Sikap terbuka, (4). Keteraturan pegawai.(5). Rasa tidak curiga. (6). Integrasi Pegawai.

Menurut Robbins (1994:108), ada 10 indikator budaya organisasi yaitu: (1) inisiatif individual, tingkat tanggung jawab, kebebasan dan independensi yang dipunyai 
individu, (2) toleransi terhadap tindakan beresiko, sejauh mana pegawai dianjurkan untuk bertindak agresif, inovatif dan mengambil resiko, (3) arah, sejauh mana organisasi tersebut menciptakan dengan jelas sasaran dan harapan mengenai prestasi, (4) integrasi, tingkat sejauh mana unit-unit dalam organisasi didorong untuk bekerja dengan cara yang terkoordinasi, (5) dukungan dari manajemen, tingkat sejauh mana para manajer memberi komunikasi yang jelas, bantuan, serta dukungan terhadap bawahan mereka, (6) kontrol, jumlah peraturan dan pengawasan langsung yang digunakan untuk mengawasi dan mengendalikan perilaku pegawai, (7) identitas, tingkat sejauh mana para anggota mengidentifikasi dirinya secara keseluruhan dengan organisasinya ketimbang dengan kelompok kerja tertentu atau bidang keahlian profesional, (8) sistem imbalan, tingkat sejauh mana alokasi imbalan (kenaikan gaji, promosi) didasarkan atas kriteria prestasi pegawai sebagai kebalikan dari senioritas, sikap pilih kasih, (9) toleransi terhadap konflik, tingkat sejauh mana para pegawai didorong untuk mengemukakan konflik dan kritik terbuka, dan (10) pola-pola komunikasi, tingkat sejauh mana komunikasi organisasi dibatasi oleh hierarki kewenangan yang formal.

Menurut Tampubolon, (2008:156), menyimpulkan indikator budaya organisasi menjadi 6 yaitu:

“1). Inovatif memperhitungkan risiko, norma yang dibentuk beradasarkan kesepakatan menyatakan bahwa setiap karyawan akan memberikan perhatian yang sensitif terhadap segala permasalahan yang mungkin dapat membuat resiko kerugian bagi kelompok dan oragnisasi secara keseluruhan. Perilaku karyawan yang demikian dibentuk apabila berdasarkan kesepakatan bersama sehingga secara tidak langsung membuat rasa tanggung jawab bagi karyawan untuk melakukan tindakan mencegah terjadi kerugian secara konsisten. Kerugian ini lebih pada waktu, dari rasa sensitifnya karyawan dapat mengantisipasi risiko yang mengakibatkan kerugian lain, seperti merusak nama baik perusahaan yang kemungkinan larinya konsumen ke produk lain.

2). Memberi perhatian pada setiap masalah secara detail, memberikan perhatian pada setiap masalah secara detail di dalam melakukan pekerjaan akan mengambarkan ketelitian dan kecermatan karyawan dalam melakukan pekerjaannya. Sikap yang demikian akan menggambarkan tingkat kualitas pekerjaan yang sangat tinggi. Apabila semua karyawan memberikan perhatian secara detail terhadap semua permasalahan yang ada dalam pekerjaaan, maka tingkat penyelesaian masalah dapat digambarkan menjadi suatu pekerjaan yang berkualitas tinggi dengan demikian kepuasan konsumen akan terpenuhi.

3). Berorientasi terhadap hasil yang akan dicapai, supervisi seorang manejer terhadap bawahannya merupakan salah satu cara manajer untuk mengarahkan dan memberdayakan staf. Melalui supervisi dapat diuraikan tujuan organisasi dan kelompok serta anggotanya, dimana tujuan dan hasil yang hendak dicapai.Apabila persepsi bawahan dapat dibentuk dan menjadi satu kesatuan didalam melakukan tugas untuk mencapai hasil.Dengan demikian semua karyawan berorientasi pada pencapaian tujuan/hasil.

4). Berorientasi kepada semua kepentingan karyawan, keberhasilan atau kinerja organisasi salah satunya ditentukan ke kompakan tim kerja (team work), di mana kerjasama tim dapat dibentuk jika manajer dapat melakukan supervisi dengan baik. 
Kerjasama tim yang dimaksud adalah setiap karyawan bekerjasama dalam persepsi dan sikap yang sama didalam melakukan pekerjaannya dan secara tidak langsung, sesama karyawan akan selalu memperhatikan permasalahan yang dihadapi masing-masing. Dengan demikian karyawan selalu berorientasi kepada sesama agar dapat tercapai target tim dan organisasi.

5). Agresif dalam bekerja, produktivitas yang tinggi dapat dihasilkan apabila performa karyawan dapat memenuhi standard yang dibutuhkan untuk melakukan tugasnya. Performa yang baik dimaksudkan antara lain: kualifikasi keahlian (ability and skill) yang dapat memenuhi persyaratan produktivitas serta harus diikuti dengan disiplin dan kerajinan yang tinggi. Apabila kualifikasi ini telah di penuhi, maka masih dibutuhkan ketahanan fisik dan keagresifan karyawan untuk menghasilkan kinerja yang baik.

6). Mempertahankan dan menjaga stabilitas kerja, performa yang baik dari karyawan harus didukung oleh kesehatan yang prima. Performa yang baik tidak akan dapat tercipta secara kontinu apabila karyawan tidak dalam kondisi kesehatan yang prima. Kesehatan yang prima akan membentuk stamina yang prima, dengan stamina yang prima akan terbentuk ketahanan fisik yang akurat (endurance) dan stabil, serta dengan endurance yang prima, maka karyawan akan dapat mengendalikan (drive) semua pekerjaan dengan baik. Dengan tingkat pengendalian yang prima, menggambarkan performa karyawan tetap prima dan stabilitas kerja dapat dipertahankan".

Berdasarkan kesesuaian fenomena yang ada di lokasi penelitian, maka indikator budaya organisasi sebagaimana yang disimpulkan oleh Hofstede (1993) merupakan indikator yang akan digunakan untuk mengukur budaya organisasi di Sekretariat DPRD Lombok Tengah pada penelitian ini.

\subsection{Kerangka Konseptual Penelitian Gambar 2.1. Kerangka Konseptual Penelitian}

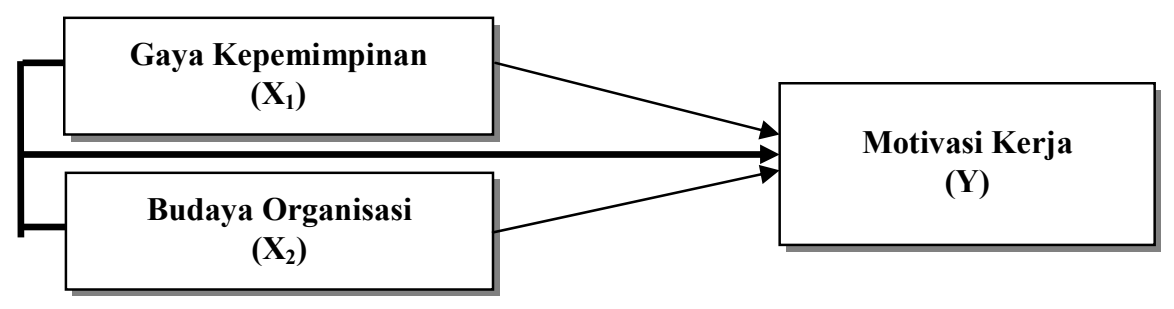

\subsection{Hipotesis}

1) Diduga Gaya Kepemimpinan dan Budaya Organisasiberpengaruh signifikan secara simultan terhadap motivasi kerja pegawai pada Sekretariat Daerah Kabupaten Lombok Tengah

2) Diduga Gaya Kepemimpinan dan Budaya Organisasiberpengaruh signifikan secara parsial terhadap motivasi kerja pegawai pada Sekretariat Daerah Kabupaten Lombok Tengah 
3) DidugaGaya Kepemimpinan memiliki pengaruh dominan terhadap motivasi kerja pegawai pada Sekretariat Daerah Kabupaten Lombok Tengah.

\section{METODE PENELITIAN}

\subsection{Jenis Penelitian}

Jenis penelitian yang digunakan dalam penelitian ini adalah penelitian Asosiatif kausal. Menurut Umar (2003:30) penelitian Asosiatif kausal adalah penelitian yang bertujuan uuntuk menganalisis hubungan antara satu variabel dengan variabel yang lain atau bagaimana variabel yang satu mempengaruhi variabel yang lain, dalam hal ini ingin mengetahui pengaruh gaya kepemimpina dan budaya organisasi terhadap motivasi kerja karyawan pada Sekretariat Daerah Kabupaten Lombok Tengah.

\subsection{Sumber Data}

1. Data primer yaitu data yang diperoleh secara langsung dari organisasi obyek penelitian, atau dalam hal ini jawaban maupun tanggpan terhadap kuesioner yang diberikan.

2. Data skunder yaitu data pendukung yang diperoleh dari organisasi atau instansi serta buku maupun literature lainnya yang berhubungan dengan masalah dalam penelitian ini.

\subsection{Teknik Pengumpulan Data}

1. Teknik Angket, yaitu pengumpulan data melalui penyebaran daftar pertanyaan kepada responden, selanjutnya hasil jawaban responden dijadikan sebagai bahan analisa untuk mendapatkan kesimpulan dalam penelitian.

2. Teknik Dokumentasi,adalah mencari data mengenai hal-hal atau variabel yang berupa catatan, transkrip, buku, surat kabar, majalah, prasasti, notulen rapat, agenda dan sebagainya (Arikunto, 2006 ;231).

\subsection{Analisa Data}

Model Analisis bergada (Multiple Regression Analysis) dengan formulasi sebagai berikut:

$$
\begin{aligned}
& Y=a+b 1 X 1+b 2 X 2+e \\
& Y=\text { Motivasi Kerja } \\
& X 1=\text { Gaya Kepemimpinan } \\
& X 2=\text { budaya organisasi } \\
& \text { b1 }=\text { koefisien regresi untuk Gaya Kepemimpinan } \\
& \text { b2 }=\text { koefisien regresi untuk Budaya Organisasi } \\
& a=\text { Nilai intercept (konstan) } \\
& \text { e = Error }
\end{aligned}
$$


Selanjutnya dari hasil perhitungan analisis regresi linier berganda tersebut dapat dilakukan analisis nilai sebagai berikut:

1. Uji F (F Test)

Untuk mengetahui pengaruh secara bersama-sama (simultan) variabel independen terhadap variabel dependen, dengan langkah-langkah pengujian sebagai berikut, Wirawan (2002:304) :

1. Menentukan hipotesis nihil dan hipotesis alternative

Ho:B1,B2=0, artinya variabel gaya kepemimpinan, dan budaya organisasi secara bersama-sama tidak berpengaruh secara signifikan terhadap motivasi kerja.

$\mathrm{H} 1: \mathrm{B} 1, \mathrm{~B} 2 \neq 0$, arinya variabel gaya kepemimpinan, dan budaya organisasi secara bersama-sama berpengaruh secara sighnifikan terhadap motivasi kerja.

2. Level of significance

Level of significance $\alpha=0,05$

Derajat kebebasan (dk) : k-1;n-k

Nilai F tabel : F 0,05; (k-1) ; (n-k)

3. Kriteria dan aturan pengujian

Gambar 3.1. Distribusi F

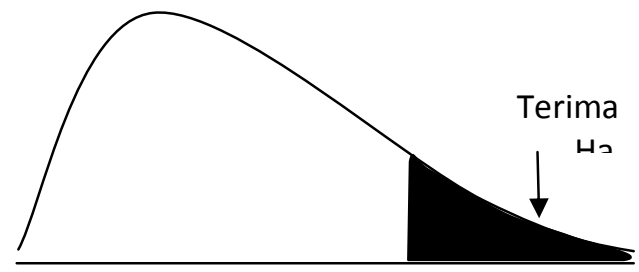

Jika $F_{\text {tabel }} \geq F_{\text {hitung }}$ maka Ho diterima, dan

Jika $\mathrm{F}_{\text {tabel }}<\mathrm{F}_{\text {hitung }}$ maka Ho ditolak.

4. Menetukan $\mathrm{F}$ hitung dengan mengunakan rumus

Dimana :

$$
F=\frac{S S R / 1}{S S E /(n-2)}
$$

$\mathrm{F}$ : nilai F hitung

SSR : Sum of Square Regression

SSE : Sum of Square Error

5. Kesimpulan

Jika $\mathrm{H}_{0}$ ditolak maka dapat disimpulkan bahwa terdapat pengaruh yang signifikan secara simultan.

\section{Uji t (t Test)}

Untuk mengetahui pengaruh secara terpisah atau parsial variable independen terhadap variabel dependen, dengan langkah-langkah pengujian sebagai berikut, Nazir (2005:459) :

1. Menentukan Hipotesis Nihil dan Hipotesis Alternatif

Ho:B1,B2 = 0, artinya variabel gaya kepemimpinan, dan budaya organisasi secara terpisah-pisah (parsial) tidak berpengaruh dominan terhadap Motivasi kerja. 


\begin{tabular}{|c|c} 
JMM & $\begin{array}{c}\text { JURNAL MAGISTER MANAJEMEN } \\
\text { UNIVERSITAS MATARAM } \\
\text { Maret } 2015\end{array}$ \\
\hline
\end{tabular}

Hi:B1,B2 $\neq 0$, artinya variabel gaya kepemimpinan dan budaya organisasi secara parsial berpengaruh secara signifikan terhadap motivasi kerja.

2. Level Of Significance $a=0,05$

Derajat kebebasan (dk) : n-1-k

$\mathrm{T}$ table $=\mathrm{t}(\mathrm{a} / 2 ; \mathrm{n}-1-\mathrm{k})$

3. Kriteria dan aturan pengujian

Gambar 3.2. Distribusi t

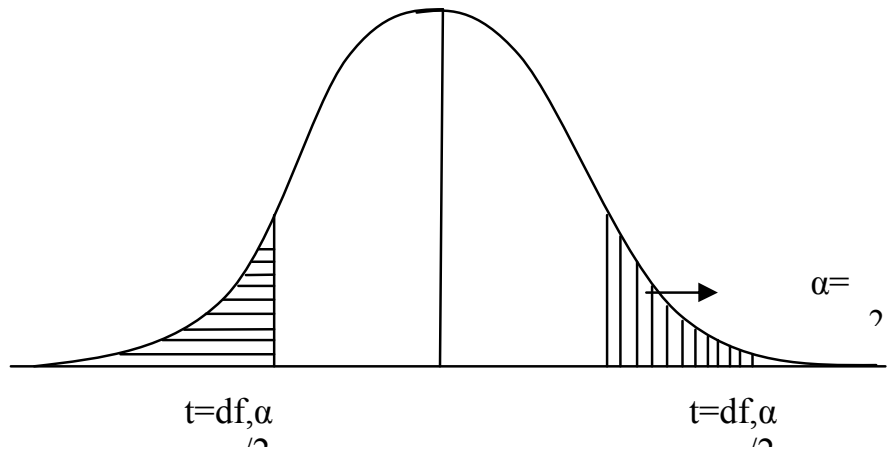

Terima Ho Jika $-\mathrm{t}_{\text {tabel }} \leq \mathrm{t}_{\text {hitung }} \leq \mathrm{t}_{\text {tabel }}$

Tolak Ho jika $-t_{\text {tabel }}>-t_{\text {hitung }}$ atau $t_{\text {hitung }}>t_{\text {tabel }}$

4. Menentukan $t$ hitung dengan rumus

di mana :

$$
t=\frac{b}{s_{b x}}
$$

$\mathrm{t}=$ nilai $\mathrm{t}$ hitung

$\mathrm{b}=$ koefisien regressi

$\mathrm{S}_{\mathrm{bx}}=$ standar estimasi untuk koefisien regressi ke- $\mathrm{x}$

\section{HASIL DAN PEMBAHASAN}

\subsection{Uji Asumsi Klasik}

\subsubsection{Uji Normalitas}

Uji normalitas melihat titik-titik pada Normal P-Plot of Regression Standardized Residual dari variabel terikat.Persyaratan uji normalitas adalah jika data menyebar di sekitar garis diagonal dan mengikuti arah garis diagonal, maka model regresi memenuhi asumsi normalitas.Jika data menyebar jauh dari garis diagonal dan / atau tidak mengikuti garis diagonal, maka model regresi tidak memenuhi asumsi normalitas. 


\begin{tabular}{|c|c|}
\hline & $\begin{array}{l}\text { JURNAL MAGISTER MANAJEMEN } \\
\text { UNIVERSITAS MATARAM } \\
\text { Maret 2015 }\end{array}$ \\
\hline
\end{tabular}

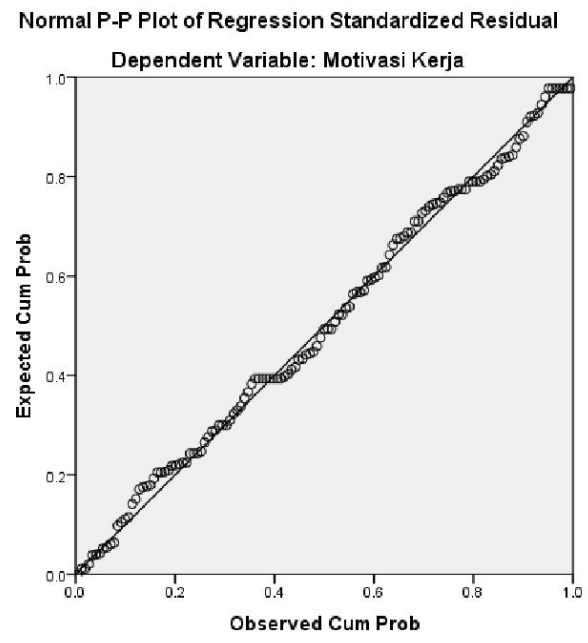

\subsubsection{Uji Multikolinearitas}

Uji multikolinieritas dilakukan dengan melihat nilai Toleransi dan VIF (Varians Inflation Faktors). Bila nilai VIF lebih kecil dari 10 dan nilai toleransinya di atas 0,1 atau $10 \%$ maka dapat disimpulkan bahwa model regresi tersebut tidak terjadi multikolinieritas (Ghozali, 2005).

\section{Tabel 4.12. Nilai VIF untuk Variabel Independen}

\begin{tabular}{|l|r|r|}
\hline \multirow{2}{*}{ riabel } & \multicolumn{2}{|c|}{ Collinearity Statistics } \\
\cline { 2 - 3 } & olerance & \multicolumn{1}{|c|}{ VIF } \\
\hline ya Kepemimpinan & 0.635 & 1,574 \\
\hline daya Organisasi & 0.635 & 1,574 \\
\hline
\end{tabular}

Sumber : Lampiran output SPSS

Dari tabel tersebut menunjukkan bahwa nilai VIF semua variabel bebas dalam penelitian ini lebih kecil dari 10 dan nilai toleransi semua variabel bebas lebih dari 0,1 yang berarti tidak terjadi korelasi antar variabel bebas, dengan kesimpulan tidak terdapat gejala multikolinieritas antar variabel bebas dalam model regresi.

\subsubsection{Uji Heterokedastisitas}

Untuk mendeteksi ada tidaknya heterokedastisitas dapat digunakan metode grafik Scatterplot yang dihasilkan dari output program SPSS Dari grafik tersebut terlihat titik-titik yang menyebar secara acak, tidak membentuk suatu pola tertentu yang jelas, serta tersebar baik di atas maupun dibawah angka 0 (nol) pada sumbu $Y$, hal ini berarti tidak terjadi penyimpangan asumsi klasik heterokedastisitas pada model regresi yang dibuat. 


\subsubsection{Uji Autokorelasi}

Setelah uji Normalitas, langkah selanjutnya adalah uji Autokorelasiyang bertujuan menguji apakah dalam suatu model regresi linear ada korelasi antara kesalahan pengganggu pada periode $t$ dengan kesalahan pada periode $t-1$ (sebelumnya).Jika terjadi korelasi maka dinamakan ada problem autokorelasi. Model regresi yang baik adalah regresi yang bebas dari autokorelasi Uji autokorelasi dilakukan dengan menggunakan uji Durbin-Watson (D-W), dengan tingkat kepercayaan $\alpha=5 \%$.

Apabila D-W terletak antara -2 sampai +2 maka tidakada autokorelasi (Santoso. 2002 : 219).Berdasarkan hasil uji SPSS diperoleh nilai D-W sebesar 1,315 sehingga dapat disimpulkan bahwa data yang digunakan dalam dalam penelitian ini tidak mengalami masalah autokorelasi.

\subsection{Analisis Regresi Linear berganda}

Berdasarkan teori yang dikemukakan oleh ahli tentang motivasi kerja dan faktor-faktor yang mempengaruhinya, maka dapat dibuat persamaan regressi sebagaimana berikut ini.

$$
y^{\wedge}=a+b 1 x 1+b 2 \times 2
$$

Di mana :

$$
\begin{array}{ll}
\mathrm{y}^{\wedge} & =\text { nilai taksir untuk variabel dependen (motivasi kerja) } \\
\mathrm{a} & =\text { nilai constan } \\
\mathrm{b} 1 & =\text { nilai koefisien regressi untuk budaya organisasi } \\
\mathrm{b} 2 & =\text { nilai koefisien regressi untuk gaya kepemimpinan } \\
\mathrm{x} 1 & =\text { Gaya Kepemimpinan, } \\
\mathrm{x} 2 & =\text { Budaya Organisasi } \\
\mathrm{ei} & =\text { error term/kesalahan uji }
\end{array}
$$

\begin{tabular}{|c|c|c|c|c|c|}
\hline \multirow[b]{2}{*}{ Model } & \multicolumn{2}{|c|}{ nstandardized Coefficients } & \multirow{2}{*}{$\begin{array}{c}\begin{array}{c}\text { Standardized } \\
\text { Coefficients }\end{array} \\
\text { Beta }\end{array}$} & \multirow[b]{2}{*}{$\mathrm{t}$} & \multirow[b]{2}{*}{ Sig. } \\
\hline & B & Std. Error & & & \\
\hline (Costanta) & 18.074 & 3.607 & & 5.011 & .000 \\
\hline $\begin{array}{c}\text { GaGaya } \\
\text { Kepemimpinan }\end{array}$ & .408 & .144 & .276 & 2.825 & .005 \\
\hline $\begin{array}{c}\text { Budaya } \\
\text { Organisasi }\end{array}$ & .316 & .152 & .203 & 2.078 & .040 \\
\hline
\end{tabular}

Berdasarkan hasil uji dengan bantuan program SPSS diperoleh nilai-nilai regressi untuk budaya organisasi sebesar 0,316 dan kepemimpinan 0,408dengan nilai konstan sebesar 18,074 seperti terlihat pada tabel berikut:

Tabel 4.14. Hasil Uji Regresi 
Sehingga dari nilai-nilai yang diperoleh tersebut dapat dibentuk model regressi untuk menguji pengaruh budaya organisasi dan kepemimpinan sebagai berikut : $\mathrm{y}^{\wedge}=18,074+0,408 \times 1+0,316 \times 2$.

Nilai ini mengindikasikan bahwa tanpa adanya pengaruh dari budaya organisasi dan gaya kepemimpinan, motivasi kerja berada pada nilai konstan 18,074. Setiap meningkatnya 1 satuan nilai x1 (gaya kepemimpinan) maka akan meningkatkan nilai motivasi kerja sebesar 0,408. Setiap meningkatnya 1 satuan nilai $x 2$ (budaya organisasi) maka akan meningkatkan nilai motivasi kerja sebesar 0,316. Nilai ini akan dapat diprediksi lebih jauh dengan menggunakan pengujian hipotesis secara simultan dan parsial sebagai berikut.

\subsubsection{Uji Hipotesis Pengaruh Simultan dan Parsial}

\section{1). Uji Hipotesis Pengaruh Simultan}

Hasil analisis regressi linier berganda menunjukkan nilai F-hitung sebesar 15,256 (lampiran 6) dengan probabilitas 0,000.Berdasarkan nilai ini, maka dilakukan pengujian dengan membandingkan nilai F-hitung dengan F-tabel. Jika F-hitung>Ftabel maka hipotesis yang menyatakan diduga gaya kepemimpinan dan budaya organisasi berpengaruh signifikan secara simultan terhadap motivasi kerja pegawai pada Sekretariat Daerah Kabupaten Lombok Tengah diterima. Tetapi jika sebaliknya F-hitung $<$ F-tabel, maka hipotesis tersebut ditolak. Berdasarkan tabel dengan df (k;n-1$\mathrm{k}=3,133$ ) pada tingkat kritis 0,05 diperoleh nilai tabel 2,605. Karena F-hitung $>$ F-tabel $(15,256>2,605)$ maka dengan demikian pada penelitian ini dapat dinyatakan bahwa gaya kepemimpinan dan budaya organisasi berpengaruh signifikan secara simultan terhadap motivasi kerja pegawai pada Sekretariat Daerah Kabupaten Lombok Tengah. Dengan demikian hipotesis 1 dinyatakan diterima.

\section{2). Uji Parsial (Uji t)}

a. Pengaruh Gaya Kepemimpinan Terhadap Motivasi Kerja

Hasil perhitungan Regressi melalui SPSS sebagaimana terlampir menunjukkan nilai $\mathrm{t}$ hitung sebesar 2,825 dan nilai probabilitas $\alpha=0,008$. Karena nilai $\mathrm{t}$ hitung lebih besar dari nilai $t$ tabel $(2,825>1,65)$ pada taraf signifikansi $5 \%$, maka pada penelitian ini hipotesis nol ditolak. artinya pada taraf signifikansi $a=5 \%$ pengaruh budaya organisasi terhadap motivasi kerjadinyatakan signifikan. Hubungan ini bersifat positif artinya semakin baik budaya organisasi yang diberikan maka semakin tinggi motivasi kerja, begitu juga sebaliknya.

b.Pengaruh Budaya Organisasi Terhadap Motivasi Kerja

Pengaruh Budaya organisasi Terhadap terhadap motivasi kerjasecara terpisah dapat dilihat dengan mengetahui besarnya standardized coefficient dan signifikansi dari pengaruh tersebut dapat diuji melalui uji $t$ (student- $t$ ).

Pada uji Regressi dengan menggunakan bantuan program SPSS diperoleh nilai $t$ hitung 2,078 untuk budaya organisasi dengan signfikansi $a=0,005$. Karena nilai t hitung lebih besar dari nilai $\mathrm{t}$ tabel $(2,078>1,65)$ pada taraf signifikansi $5 \%$, maka pada penelitian ini hipotesis nol ditolak. Artinya pada taraf signifikansi $\mathrm{a}=5 \%$ pengaruh 
budaya organisasi terhadap motivasi kerjadinyatakan signifikan. Hubungan ini bersifat positif artinya semakin baik budaya organisasi yang diberikan maka semakin tinggi motivasi kerja, begitu juga sebaliknya

c. Kekuatan Pengaruh Setiap Variabel Pada Motivasi Kerja

Untuk mengetahui kekuatan pengaruh setiap variabel terhadap motivasi kerja, maka pada penelitian ini menggunakan koefisien determinasi dan standardized coefficient beta. Koefisien determinasi menunjukkan besaran 0,185 yang mengindikasikan bahwa variasi dari motivasi kerjapegawai dipengaruhi oleh faktor-faktor budaya organisasi dan kepemimpinan sebesar 0,185 (18,5\%). Sedangkan sisanya 81,5\% dipengaruhi oleh faktor lain yang tidak dimasukkan dalam model (yang tidak diteliti). Sedangkan untuk mengetahui variabel mana yang paling kuat mempengaruhi stress kerja maka digunakan standardized coefficient beta sebagaimana yang terlihat pada tabel di bawah ini.

Tabel 4.14.standardized coefficient beta setiap variabel

\begin{tabular}{|l|r|r|}
\hline \multirow{2}{*}{ riabel } & \multicolumn{2}{|c|}{$\begin{array}{c}\text { standardized coefficient } \\
\text { beta }\end{array}$} \\
\cline { 2 - 3 } & oefficient & Peringkat \\
\hline daya Organisasi & 0,203 & 1 \\
\hline ya Kepemimpinan & 0,276 & 2 \\
\hline
\end{tabular}

Tabel di atas menunjukkan bahwa variabel yang paling kuat mempengaruhi motivasi kerja pegawai adalah gaya kepemimpinandan bersifat positif dengan nilai 0,276. Dengan demikian hipotesis dalam penelitian ini yang menyatakan bahwa gaya kepemimpinan merupakan faktor yang dominan mempengaruhi motivasi kerja dapat diterima.

\section{SIMPULAN DAN SARAN}

\subsection{Simpulan}

1. Gaya kepemimpinan dan budaya organisasi berpengaruh signifikan secara simultan terhadap motivasi kerja pegawai pada Sekretariat Daerah Kabupaten Lombok Tengah. Secara menyeluruh gaya kepemimpinan dan budaya organisasi mampu merubah motivasi kerja pegawai pada Sekretariat Daerah Kabupaten Lombok Tengah.

2. Gaya kepemimpinan dan budaya organisasi berpengaruh signifikan secara parsial terhadap motivasi kerja pegawai pada Sekretariat Daerah Kabupaten Lombok Tengah.Gaya kepemimpinan dan budaya organisasi dapat menjelaskan variasi motivasi kerja pegawai pada Sekretariat Daerah Kabupaten Lombok Tengah secara sendiri-sendiri.

3. Gaya kepemimpinan mempunyai pengaruh yang lebih dominan dibandingkan dengan faktor budaya organisasi. Kemampuan pemimpin untuk mengarahkan pegawainya merupakan motivasi yang lebih tinggi bagi pegawai untuk 
melaksanakan pekerjaan dilingkungan Sekretariat Daerah Kabupaten Lombok Tengah.

\subsection{Saran}

1. Untuk meningkatkan budaya organisasi yang kondusif, dinas harus berusaha untuk mempertahankan apa yang selama ini telah berlangsung dengan baik, dan mengurangi hal-hal yang merupakan kebiasaan buruk dalam bekerja.Hal ini misalnya dapat dilakukan dengan menciptakan suasana kondusif yang menghilangkan rasa saling curiga antara pegawai.Cara yang dilakukan adalah dengan melakukan transparansi kegiatan atau program-program kerja yang ada di Sekretariat Daerah Kabupaten Lombok Tengah.

2. Kepemimpinan yang dilakukan selama ini sudah cukup baik, tetapi sangat diharapkan untuk para pemimpin supaya bisa lebih dekat dan mengakomodir dan mengetahui apa yang diharapkan oleh pegawai. Kepedulian pimpinan baik pimpinan tertinggi maupun pimpinan setiap bidang yang ada untuk mau mendengarkan saran, masukan dan ide bawahan, maupun keluhan-keluhan yang sifatnya pribadi, serta pemimpin diharapkan untuk meningkatkan pemahamannya terhadap reaksi pegawai yang akan muncul dari setiap tindakan dan keputusan yang diambil.

3. Untuk lebih meningkatkan motivasi karyawan diharapkan agar meningkatkan kebiasaan memberikan pujian terhadap hasil kerja karyawan. Hal ini merupakan bentuk perhagaan secara langsung yang diterima karyawan sehingga mampu member semangat dalam bekerja.

\section{Daftar Pustaka}

Arikunto, S., 2006, Prosedur Penelitian, Jakarta, Teplok Pisress.

Cahyono, B., 2005, Pengaruh Gaya Kepemimpinan, Budaya Organisasi dan Lingkungan Kerja Terhadap Motivasi Kerja, Thesis, Universitas Brawijaya.

Greenberg, Jerald dan Robert A. Baron.(2003). Behavior in Organizations.International Edition. Eight Edition. Prentice Hall, New Jersey.

Gibson,J. L. (1996), Organisasi: Perilaku, Struktur dan Proses. Jakarta: Bina Rupa Aksara

Ghozali, I., 2005, Aplikasi Analisis Multivariate Dengan Program SPSS.Semarang : UNDIP.

Goelman, et.al., 2004, Kepemimpinan Berdasarkan EQ. Jakarta : GPU

Handoko, T.H.,1995. Manajemen personalia dan sumber daya manusia.Yogyakarta :BPFE. Hasibuan, Malayu S.P., 2010, Manajemen Sumber Daya Manusia, Jakarta: PT Bumi Aksara. 
Hofstede, G. 1993. Cultural and Dimension in People Management: The. Socialization Perspective.John Wiley \& Sons, Inc. New York. Husein

Kreitner, Robert dan Kinicki, A., 2010. Perilaku Organisasi, Terjemahan: Erly Suandy, Edisi Pertama, Penerbit Salemba Empat, Jakarta.

Nugraheny,S., 2009, Analisis Pengaruh Kepuasan Kerja, Dukungan Organisasi Dan Gaya Kepemimpinan Terhadap Motivasi Dalam Meningkatkan Kinerja Karyawan (Studi Pada PT. Bank Mandiri Persero Tbk Kota Semarang), Thesis Magister.

Nuroctaviana, 2011, Pengaruh Budaya Organisasi Terhadap Motivasi Kerja, Kepuasan Kerja dan Kinerja Karyawan (Studi Pada PT. Mirota), thesis magister.

Robbins, S., 2003, Perilaku Organisasi, Jakarta: Salemba Empat. Jilid I, Edisi Indonesia, Jakarta : Prenhallindo.

Sofyandi, H., dan Iwa G., 2007, Perilaku Organisasional. Yogyakarta: Graha Ilmu.

Soetopo,H.,2010, Kepemimpinan Pendidikan, FIP UM, Malang.

Subhan, 2012, Pengaruh Gaya Kepemimpinan Terhadap Motivasi Kerja Karyawan Dilingkungan Rektorat Universitas Mataram, Thesis Magister, UNRAM, Mataram.

Sujarwadi,P.A., 2012, Pengaruh gaya kepemimpinan terhadap kinerja pegawai Rumah Sakit Umum Provinsi Nusa Tenggara Barat, Thesis Magister, UNRAM, Mataram.

Thoha, M. (2010), Kepemimpinan dan Manajemen, Devisi Buku Perguruan Tinggi, PT. Raja Grafindo Persada, Kakarta.

Umar, H., 2003, Metode Penelitian Untuk Skripsi, Thesis Bisnis, Jakarta, PT. Raja Graindo Persada.

Uno, H.B., 2009, Teori Motivasi dan Pengukurannya: Analisis di Bidang Pendidikan, Bumi Aksara, Jakarta.

Wibowo,A,2008, Analisis Pengaruh Budaya Organisasi dan Kepuasaan Kerja Terhadap Motivasi Kerja dan Kinerja Karyawan (Studi pada unit Kantor Cabang BRI Pattimura Semarang), Thesis Magister, Brawijaya, Malang.

Wirawan, Nata. 2002. Cara Mudah Memahami Statistik 2 (Statistik Inferensia) Untuk Ekonomi dan Bisnis. Edisi Kedua. Denpasar: Keramat Emas. 